\title{
Unravelling the Relationship between Ecosystem-Based Management, Integrated Coastal Zone Management and Marine Spatial Planning
}

\author{
Martin Le Tissier
}

\begin{abstract}
Coastal zones are among the most productive areas in the world, offering a wide variety of valuable habitats and ecosystems services that have attracted humans and human activities over millennia. But equally coastal zones are also among the most vulnerable areas to climate change, natural hazards and other anthropogenic perturbations. The impacts of coastal change are far reaching and are already changing the wellbeing of coastal communities. It is essential to make use of long-term management tools to enhance the conservation of coastal resources whilst increasing the sustainability of their uses. Integrated Coastal Management (ICM) and Marine Spatial Planning (MSP) are both tools that attempt to override traditional sectoral approaches that lead to disconnected decisions and missed opportunities for more sustainable coastal development. Ecosystem-Based Management (EBM) describes the comprehensive integrated management of human activities based on the best available scientific knowledge to achieving sustainable use of ecosystem goods and services and maintenance of ecosystem integrity. However, there is a degree of contradiction regarding the juxtaposition of EBM to ICM and $\mathrm{MSP}$ - does it underpin and coordinate the implementation of them or does ICM and MSP coordinate the application of EBM principles to management practices and goals or does the difference in terminology detract from the real challenge of achieving sustainability of the world's coastal and marine areas? This chapter provides insights into the juxtaposition of these concepts and suggests a promising future approach founded on Biodiversity Portfolio Analysis (BPA).
\end{abstract}

\section{Lessons Learned}

- Adherence to terminology rather than end goals can blur the emphasis and principles of processes needed to address environmental challenges in coastal and marine areas.

\footnotetext{
M. Le Tissier ( $\square)$

MaREI Center for Marine and Renewable Energy, Beaufort Building, Environmental Research Institute, University College Cork, Co. Cork, Ireland

e-mail: martin.letissier@ucc.ie
} 
- There is a need to recognise the coastal and marine environment as a portfolio of constituent elements that need to be managed as a cohesive whole.

- Principles and processes of EBM need to be juxtaposed with other methods and tools for understanding environmental challenges faced by society now and in the future.

\section{Needs to Advance EBM}

- Stronger inculcation of societal elements and their explicit inclusion in EBM principles and processes is a necessary requirement.

- Developing a coherent approach to link EBM with existing policy processes and outcomes is important.

\section{Introduction}

Scientific and policy communities have increasingly recognised that complex environmental problems are an existential threat to humanity that require integrative, interdisciplinary approaches to understand and manage the interaction between social and ecological systems (Binder et al. 2015; Defries and Nagendra 2017). Concurrently, there is also a growing recognition that environmental change is experienced at many inter-related scales from local to global with cause and impact also ranging from near to distant (Adger and Brown 2010). Whilst the sciences have quantified and documented environmental change and its consequences [op. cit.], research has also shown that human activities are largely behind the driving forces that are the proximate causes of environmental change (Stern et al. 1992).

Formal concepts of ecosystem management initially arose in the 1970s aligned to wildlife management and were first transferred to the marine environment as part of the United Nations Conference on the Law of the Sea (UNCLOS) (Forst 2009; Long et al. 2015). Environmental policies increasingly advocate a holistic approach to coastal and marine resource management (Buhl-Mortensen et al. 2017) that address an increasing degree of anthropogenic pressures on coastal and marine environments as well as conflicts between multiple users competing for space and resources. The Ecosystem Approach (EA) is a strategy that underpins the objectives of the Convention on Biological Diversity as "a strategy for the integrated management of land, water and living resources that promotes conservation and sustainable use in an equitable way" (CBD 2000), and is widely referred to as Ecosystem-based Management or EBM (Long et al. 2015). EA is embedded in the concept of sustainable development, which requires that the needs of future generations are not compromised by the actions of people today, and puts emphasis on a management regime that maintains the health of the ecosystem alongside appropriate human use of the marine environment, for the benefit of current and future generations (ICES 2005; Defries and Nagendra 2017). Key features of EBM centre around notions that management should be holistic and not focused on single sectors or species [c.f., Garcia et al. 2003] and directed to managing human activities and their impacts on 
ecosystems rather than the ecosystem itself (Leslie and McLeod 2007). However, the reality has been that both scientific research and management programmes have applied concepts of EBM with very diverse variations in emphasis, definition of terms and application of principles (Yaffee 1999; Arkema et al. 2006; Sardà et al. 2014; Long et al. 2015). In large part this is because there has been a mismatch in institutional arrangements (Alexander and Haward 2019) where Integrated Coastal Management (ICM) and Marine Spatial Planning (MSP) have been employed to redress a traditional sectoral focus of marine environmental and resource management (Ehler and Douvere 2009; Freestone et al. 2010; UNEP 2010; Smith et al. 2017) and have stronger policy and governance as well as management components (Javier 2015). ICM and MSP have had greater policy presence because they are seen as providing a means to improve decision making by providing a framework to analyse competing human activities and managing their impact on the marine environment (Buhl-Mortensen et al. 2017).

\section{Unravelling EBM, ICM and MSP}

Degradation of coastal and marine ecosystems is an often cited impact of environmental change (e.g., Stern et al. 1992; Arkema et al. 2006; Alexander and Haward 2019), and is a consequence of post-1900 industrialisation and post-World War II economic and population growth (Yasuhara et al. 2012), which have increasingly seen both human migration to the world's coastal zones and exploitation of coastal and marine space and resources as demand has outstripped availability of land-based space and resources (Caddy and Grithiths 1995; Long et al. 2015). EBM has been advocated as a key pillar in the sustainable management of coastal zones and marine areas in conjunction with ICM and MSP respectively (UN Environment 2018; Langlet and Rayfuse 2019).

There is an ever-growing, largely academic, literature that debates the relationship between the definitions and roles of EBM with ICM and MSP (see for example, Haines-Young and Potschin 2011; NOAA 2011; Aswani et al. 2012; Celliers et al. 2016) in the context of whether one is subsumed within the other (Golitsyn 2010) and the legal basis and definitions of these terms in different jurisdictions are discussed in detail in this volume (See Enright and Boteler 2020; O'Hagan 2020; Harwell 2020). The aims of ICM and MSP whilst principle-based, in common with EBM, are primarily place-based in their implementation in order to:

- Reduce conflicts, and enhance synergies, between sectors and their activities, and

- Protect and conserve the environment and its resources upon which those activities are dependent.

ICM and MSP seek to achieve these objectives by: 
- Integrating between levels of government and other management authorities (including across administrative boundaries),

- Integrating between disciplines, and

- Integrating across spatial and temporal scales.

Although EBM essentially includes much of these aims and objectives it differs in its sense of 'place', which is focussed on ecosystem units rather than sectoral activities and, whilst acknowledging that humans are part, are dependent on and occur with the ecosystem, places a different emphasis of management objectives. The consequence is that EBM can place an unequal weighting to the three tenets of sustainable development-environmental, economic and social equity-and lead to the view of human activity as impacts to ecosystem long-term viability and longevity. In contrast, MSP and ICM are essentially planning processes that seek to overcome the fragmentation in single-sector management approaches and analyse and organise human activities in coastal and marine areas to achieve economic and social objectives whilst safeguarding ecological integrity (Sandersen et al. 2013). Thus ICM and MSP have evolved with a greater emphasis towards designing rules and procedures for how to govern an area (Rodriguez 2017). This can lead to decisions that emphasises a 'balance' between protection of the environment and the maintenance and development of coastal and marine dependent economies: such a perspective is inherent to many coastal and marine strategies such as the EU integrated maritime policy (European Commission 2007). Therefore, whilst EBM has evolved to include many of the same principles as ICM and MSP (Haines-Young and Potschin 2011) it has a greater emphasis on conserving ecosystems and ecosystem services, which brings in additional management challenges over and above merging sectoral approaches to exploitation of coastal and marine space and resources (Golitsyn 2010). What this has meant is that, regardless of the terminology used, the practices of EBM by implementing authorities have tended to focus on applying an EBM approach to inform strategies and plans that seek to promote the sustainable growth of coastal and maritime economies, the sustainable development of marine areas and the sustainable use of marine resources. For instance the EU Marine Strategy Framework Directive as the environmental pillar of the EU's crosscutting Integrated Maritime Policy, and aspects of the National Environmental Policy Act (NEPA) in the USA.

\section{Current Coastal and Marine Management Regimes}

The coastal and marine environment and its resources have been managed through fragmented and sectoral approaches (Altvater and Passarello 2018; Kelly et al. 2018) that fail to incorporate the complexity and interconnection of marine ecosystems and the cumulative pressures that different human activities have on species and habitats (see O'Hagan 2020 for discussion on the dominance of the Common Agricultural Policy and the Common Fisheries Policy over activities within the environment for 
Europe). EBM is described as an integral component of management regimes, such as ICM and MSP (Kittinger et al. 2014; Robinson et al. 2014; Javier 2015), but has developed in a number of parallel approaches leading to a plethora of terminology and variation in the detail of principles depending on the ultimate management interest. Essentially the recognition of the importance of EBM within any management approaches is centred on acknowledging the relationship of ecosystem services to human welfare and emphasising the need for tools that encourage coordination and cooperation, participation, transparency, public interest, etc., to achieve the governance of these spaces. At the same time, the increasing interest in developing new uses and activities bring an important concern about its environmental consequences (NOAA 2011). A further benefit of EBM is its focus on natural boundaries and interconnections rather than the 'un-natural' administrative boundaries that characterise social and economic organisation (Paxinos et al. 2008; Environmental Law Institute 2009a; UNEP 2012). Therefore, EBM may be viewed as a process that implements the concepts of an Ecosystem Approach into planning management regimes for coastal and marine areas (Douvere 2008; Ansong et al. 2017).

The expectation that EBM with ICM and MSP can close the gaps between societal objectives and the state of the environment is great (Karlsson 2019). Many nations and regions have management regimes that seek to harmonise laws, policy, plans and strategies within prevailing institutional arrangements to achieve sustainable development of coastal and ocean space that balance different uses of the space and resources (Balgos et al. 2005). Increasingly, EBM has been applied to coastal and marine areas to incorporate both environmental and non-environmental factors into management regimes in order to inculcate human systems as components of the natural environment (Domínguez-Tejo et al. 2016). These initiatives seek to embed EBM as a procedure to ensure that management processes achieve an equitable and sustainable balance between conservation of the environment and persistence of ecosystem services into the future with the multiple demands on coastal and marine space and resources (Rodriguez 2017). The practical application of EBM within management regimes has recognised that there is a divergence from theory depending on political and socio-economic priorities (Jones et al. 2016) but that EBM provides opportunities to address challenges of functional metrics and indicators, spatial and temporal measures to address multiple and cumulative uses of resources, integration across sectors and adaptive management (Rodriguez 2017).

There is a growing awareness that management regimes, and the way they are informed by EBM approaches, need to be updated to account for contradictory environmental/societal and economic/stakeholder goals that can incentivise an economic and environmental perspective to act against each other (Breen et al. 2012). Furthermore, EBM, ICM and MSP need to evolve methodologies that better account for the consequences of current and future scenarios of development and uses of coastal and marine areas. 


\section{The Future}

The academic debate over the supremacy and juxtaposition of EBM, ICM and MSP terms (and their variants) of one above the other perhaps misses the point that they all purport to have a primary objective oriented around concepts of sustainable development, which is principally about meeting the needs of the present without compromising those of the future (Brundtland 1987; Holden et al. 2014). To deliver 'sustainability', and develop an organisational methodology for the integrated management of natural resources requires approaches that complements but go beyond 'classical' conservation concepts such as endangered species or habitat protection and various types of protected area designations (English Nature 2003). Such considerations lie behind concepts that seek to extend ideas of humans as an integral component of the ecosystem (Millennium Ecosystem Assessment 2005) to those of humanity existing within planetary boundaries (Raworth 2012; Dearing et al. 2014) and ecosystem services. However, assessing the diversity of social relationships with coasts and marine space can prove difficult for scientists and practitioners in order to protect and conserve the services and benefits they provide (Kittinger et al. 2014). In particular outstanding challenges exist in regard to the spatial distribution of social, environmental and economic values; contrasting across different types of uses and their cumulative effects; addressing risk and uncertainty; and the juxtaposition of administrative and jurisdictional boundaries versus ecological boundaries (Domínguez-Tejo et al. 2016). This presents barriers to incorporating social dimensions of marine ecosystems into ecosystem-based management, which can in turn affect the success of planning and management initiatives encompassed by ICM and MSP.

Sustainable development is often addressed as a finite utopian vision of some 'perfect' future. However, sustainable development is increasingly viewed as a process - or transformative pathway-towards a largely unknown (or uncertain) future that can change over time and space whereby concepts of adaptation and resilience hold greater importance (Denton et al. 2014; Feola 2015; Romero-Lankao et al. 2016). Management of coastal and marine space and resources often focuses on "islands" of high value ecosystems, in terms of economic value or conservation (Hills et al. 2009). However, integrated management requires land and seascapelevels analysis of all ecosystem values from both monetary and non-monetary perspectives. In viewing sustainable development as a pathway the opportunity for the balance between different elements-environmental, economic and social—can vary over time and space. In actuality coastal and marine spaces are a mosaic of different interests vying for the 'best' return on activities whether they are conflictory or complementary, exploitative or conservationist. Furthermore, relative returns can vary over time and space. In practice, this means that successful EBM needs to incorporate analyses of risk and return to ensure that management outcomes lead to greater security across all elements-human and environment—of coastal and marine systems over short and long timescales. 
The Biodiversity portfolio Analysis (BPA) method is derived from the logic used in share (equity) portfolio management in terms of balancing within a portfolio the returns with the risks (Figge 2001; Breen et al. 2012). Optimising the returns from a share portfolio, or a suite of ecosystems in a landscape, is dependent on the relationship between the units in terms of risk and return in time and space. This leads to an approach that more approximates with portfolio management that provides flexibility to adapt and adjust over time and space as situations change (Hills et al. 2009; Breen and Hynes 2014)—especially given the uncertainty associated with all three pillars of sustainability. It has been suggested that BPA as part of a holistic management approach could lead to strategies that 'favour' conservation as a longer term strategy maintaining future options in comparison with current management approaches that can be 'weighted' towards sustaining the status quo of existing coastal and marine use with less emphasis on future potential development and opportunities (Figge 2001; Hills et al. 2009; Breen et al. 2012). In practice this means that drawing distinctions between pillars of sustainability and assigning a hierarchy of one over the other is likely to be counterproductive. ICM and MSP influence the spatial and temporal distribution of human activities and, to attain sustainable development, can only be effective if EBM, with its focus on the costs and benefits that ecosystem services provide, runs concurrently (Douvere and Ehler 2006; Environmental Law Institute 2009a, b; Forst 2009; Soma et al. 2015; Hummel et al. 2017; Altvater and Passarello 2018). In this way sustainable development of coastal and marine spaces can be achieved through:

- Addressing the heterogeneity of coastal and marine areas to reflect the interdependency of ecology and human activities upon each other.

- Influencing the behaviour of humans and their activities over time in a way that respects ecological limitations and boundaries.

- Addressing the conflicts and compatibility issues that arise from different human activities targeting the same ecological resources and/or different ecological resources from the same space.

- Steering single-sector management to become integrated across multiple sector decision making.

The complexity of managing coastal and marine areas is ever increasing as growing populations identify more uses for the services and benefits provided by the world's coastal and marine areas, and build the capacity to exploit opportunities (Francis et al. 2019). As the number and variety of both possible uses of coastal and marine spaces, and interest groups pursuing uses, escalates it is important to be able to assess the effect of management regimes not only in the short term but over medium and longer term planning horizons. A portfolio tactic allows an assessment to be made of a range of possible scenarios the outcomes from an EBM approach to achieve a sustainable future, whilst minimising the risk to that objective. 


\section{References}

Adger, W. N., \& Brown, K. (2010). Progress in global environmental change. Global Environmental Change, 20, 547-549. https://doi.org/10.1016/j.gloenvcha.2010.07.007.

Alexander, K. A. A., \& Haward, M. (2019). The human side of marine ecosystem-based management (EBM): 'Sectoral interplay' as a challenge to implementing EBM. Marine Policy, 101, 33-38. https://doi.org/10.1016/j.marpol.2018.12.019.

Altvater, S., \& Passarello, C. (2018). Policy brief implementing the ecosystem-based approach in maritime spatial planning. Available at: https://www.msp-platform.eu/sites/default/files/ 20181025_ebainmsp_policybrief_mspplatform.pdf. Accessed 11 May, 2020.

Ansong, J., Gissi, E., \& Calado, H. (2017). An approach to ecosystem-based management in maritime spatial planning process. Ocean \& Coastal Management, 141, 65-81. https://doi. org/10.1016/j.ocecoaman.2017.03.005.

Arkema, K. K., Abramson, S. C., \& Dewsbury, B. M. (2006). Marine ecosystem-based management: From characterization to implementation. Frontiers in Ecology and the Environment, 4, 525-532. https://doi.org/10.1890/1540-9295(2006)4[525,MEMFCT]2.0.CO;2.

Aswani, S., Christie, P., Muthiga, N. A., et al. (2012). The way forward with ecosystem-based management in tropical contexts: Reconciling with existing management systems. Marine Policy, 36, 1-10. https://doi.org/10.1016/j.marpol.2011.02.014.

Balgos, M. C., Ricci, N., Walker, L., et al. (2005). Compilation of summaries of National and Regional Ocean Policies. The Nippon Foundation Research Task Force on National Ocean Policies.

Binder, C. R., Pahl-wostl, C., \& Knieper, C. (2015). Frameworks for analyzing social-ecological systems. Available at: https://www.tias-web.info/wp-content/uploads/2015/07/Frameworksfor-SES-analysis_CB-small.pdf. Accessed 11 May, 2020.

Breen, B., \& Hynes, S. (2014). Shortcomings in the European principles of Integrated Coastal Zone Management (ICZM): Assessing the implications for locally orientated coastal management using Biome Portfolio Analysis (BPA). Marine Policy, 44, 406-418. https://doi.org/10.1016/j. marpol.2013.10.002.

Breen, P., Robinson, L. A., Rogers, S. I., et al. (2012). An environmental assessment of risk in achieving good environmental status to support regional prioritisation of management in Europe. Marine Policy, 36, 1033-1043. https://doi.org/10.1016/j.marpol.2012.02.003.

Brundtland, G. H. (1987). Report of the World Commission on environment and development: Our common future. United Nations.

Buhl-Mortensen, L., Galparsoro, I., Vega Fernández, T., et al. (2017). Maritime ecosystem-based management in practice: Lessons learned from the application of a generic spatial planning framework in Europe. Marine Policy, 75, 174-186. https://doi.org/10.1016/j.marpol.2016.01. 024.

Caddy, J. F., \& Grithiths, R. C. (1995). Living marine resources and their sustainable development: Some environmental and institutional perspectives. FAO Fisheries Technical Paper. No. 353. FAO, Rome.

CBD. (2000). Report of the Fifth meeting of the conference of the parties to the convention on biological diversity.

Celliers, L.,Taljaard, S., van Niekerk, L. (2016). MSP, ICM, ABM, and EBM - the alphabet of confusion? Presented at the 13th Biodiversity Planning Forum, George, South Africa 9 June 2016.

Dearing, J. A., Wang, R., Zhang, K., et al. (2014). Safe and just operating spaces for regional socialecological systems. Global Environmental Change, 28, 227-238. https://doi.org/10.1016/j. gloenvcha.2014.06.012.

Defries, R., \& Nagendra, H. (2017). Ecosystem management as a wicked problem. Science (80-), 270, 265-270. https://doi.org/10.1126/science.aal1950.

Denton, F., Wilbanks, T. J., Abeysinghe, A. C., et al. (2014). Climate-resilient pathways: Adaptation, mitigation, and sustainable development. Cambridge, UK: Cambridge University Press. 
Domínguez-Tejo, E., Metternicht, G., Johnston, E., \& Hedge, L. (2016). Marine spatial planning advancing the ecosystem-based approach to coastal zone management: A review. Marine Policy, 72, 115-130. https://doi.org/10.1016/j.marpol.2016.06.023.

Douvere, F. (2008). The importance of marine spatial planning in advancing ecosystem-based sea use management. Marine Policy, 32, 762-771. https://doi.org/10.1016/j.marpol.2008.03.021.

Douvere, F., \& Ehler, C. (2006). Issues and prospects. Ecosystem-based marine spatial management: An evolving paradigm for the management of coastal and marine places. Ocean Yearbook, 23, 1-26.

Ehler, C., \& Douvere, F. (2009). Marine spatial planning: A step-by-step approach toward ecosystem-based management. Intergovernmental Oceanographic Commission and Man and the Biosphere Programme. IOC Manual and Guides No. 53, ICAM Dossier No. 6. Paris: UNESCO.

English Nature. (2003). Adopting an ecosystem approach for improved stewardship of the maritime environment: Some overarching issues. English Nature Research Reports Number 538.

Enright, S.R., \& Boetler, B. (2020). The ecosystem approach in international law. In T. O'Higgins, M. Lago, \& T. H. DeWitt (Eds.), Ecosystem-based management, ecosystem services and aquatic biodiversity: Theory, tools and applications (pp. 333-352). Amsterdam: Springer.

Environmental Law Institute. (2009a). Expanding the use of ecosystem-based management in the Coastal Zone Management Act. Environmental Law Institute (ELI).

Environmental Law Institute. (2009b). Ocean and coastal ecosystem based management. Implementation handbook. Washington, DC: Environmental Law Institute ${ }^{\circledR}$.

European Commission. (2007). SEC(2007) 1280. An Integrated Maritime Policy for the European Union. Impact assessment summary. European Commission.

Feola, G. (2015). Societal transformation in response to global environmental change: A review of emerging concepts. Ambio, 44, 376-390. https://doi.org/10.1007/s13280-014-0582-z.

Figge, F. (2001). Managing biodiversity correctly—efficient portfolio management as an effective way of protecting species. Centre for Sustainability Management, University of Luneburg.

Forst, M. F. (2009). The convergence of Integrated Coastal Zone Management and the ecosystems approach. Ocean \& Coastal Management, 52, 294-306. https://doi.org/10.1016/j.ocecoaman. 2009.03.007.

Francis, T. B., Levin, P. S., Punt, A. E., et al. (2019). Linking knowledge to action in ocean ecosystem management: Elementa. https://doi.org/10.1525/elementa.338

Freestone, D., Cicin-Sain, B., Hewawasam, I., \& Hamon, G. (2010). Draft policy brief on improving governance: Achieving integrated, ecosystem-based ocean and coastal management. 5th Global Conference on Oceans, Coasts and Islands, p 22.

Garcia, S. M., Zerbi, A., \& Aliaume, C., et al. (2003). The ecosystem approach to fisheries. Issues, terminology, principles, institutional foundations, implementation and outlook. FAO Fisheries Technical Paper. No. 443. Rome: FAO.

Golitsyn, V. (2010). Major challenges of globalisation for seas and oceans: Legal aspects. In D. Vidas (Ed.), Law, technology and science for oceans in globalisation (pp. 59-73). Brill Academic Publisher.

Gopnik, M. (2008). Integrated marine spatial planning in U.S. waters: The path forward. The Marine conservation initiative. Gordon and Betty Moore Foundation.

Haines-Young, R., \& Potschin, M. (2011). Integrated coastal zone management and the ecosystem approach. Deliverable D2.1, PEGASO Grant agreement no: 244170. CEM Working Paper No 7.

Harwell, D. R. (2020). Ecosystem services in U.S. environmental law and governance for the ecosystem-based management practitioner. In T. O'Higgins, M. Lago, \& T. H. DeWitt (Eds.), Ecosystem-based management, ecosystem services and aquatic biodiversity: Theory, tools, and applications (pp. 373-402). Amsterdam: Springer.

Hills, J., Carlisle, M., Le Tissier, M., et al. (2009). Landscape-scale analysis of ecosystem risk and returns: A new tool for ICZM. Marine Policy, 33, 887-900. https://doi.org/10.1016/j.marpol. 2009.04.017. 
Holden, E., Linnerud, K., \& Banister, D. (2014). Sustainable development: Our common future revisited. Global Environmental Change, 26, 130-139. https://doi.org/10.1016/j.gloenvcha. 2014.04.006.

Hummel, C., Provenzale, A., Van Der Meer, J., et al. (2017). Ecosystem services in European protected areas: Ambiguity in the views of scientists and managers? PLoS One, 12, e0187143. https://doi.org/10.1371/journal.pone.0187143.

ICES. (2005). Guidance on the application of the ecosystem approach to management of human activities in the European Marine Environment. ICES Cooperative Research Report No. 273.

Javier, G. S. (2015). The approach of integrated coastal zone management: From technical to political point of view. Journal of Coastal Zone Management, 18, 2-4. https://doi.org/10.4172/ 2473-3350.1000e111.

Jones, P. J. S., Lieberknecht, L. M., \& Qiu, W. (2016). Marine spatial planning in reality: Introduction to case studies and discussion of findings. Marine Policy, 71, 256-264. https:// doi.org/10.1016/j.marpol.2016.04.026.

Karlsson, M. (2019). Closing marine governance gaps? Sweden's marine spatial planning, the ecosystem approach to management and stakeholders' views. Ocean \& Coastal Management, 179, 104833. https://doi.org/10.1016/j.ocecoaman.2019.104833.

Kelly, C., Ellis, G., \& Flannery, W. (2018). Conceptualising change in marine governance: Learning from transition management. Marine Policy, 95, 24-35. https://doi.org/10.1016/j. marpol.2018.06.023.

Kittinger, J. N., Koehn, J. Z., Le Cornu, E., et al. (2014). A practical approach for putting people in ecosystem-based ocean planning. Frontiers in Ecology and the Environment, 12, 448-456. https://doi.org/10.1890/130267.

Langlet, D., \& Rayfuse, R. (2019). The ecosystem approach in ocean planning and governance: Perspectives from Europe and beyond. Leiden: Brill Nijhoff.

Leslie, H. M., \& McLeod, K. L. (2007). Confronting the challenges of implementing marine ecosystem-based management. Frontiers in Ecology and the Environment, 5, 540-548. https://doi.org/10.1890/060093.

Long, R. D., Charles, A., \& Stephenson, R. L. (2015). Key principles of marine ecosystem-based management. Marine Policy, 57, 53-60. https://doi.org/10.1016/j.marpol.2015.01.013.

Millennium Ecosystem Assessment. (2005). Ecosystems and human well-being: Synthesis. A report of the Millennium Ecosystem Assessment. World Resources Institute.

NOAA. (2011). Clarifying the relationships among ecosystem based management; integrated ecosystem assessments; and, coastal and marine spatial planning. NOAA response to SAB/ESMWG letter of April 5, 2010. NOAA.

O'Hagan, A. M. (2020). Ecosystem-based management (EBM) and ecosystem services in EU law, policy and governance. In T. O'Higgins, M. Lago, \& T. H. DeWitt (Eds.), Ecosystem-based management, ecosystem services and aquatic biodiversity: Theory, tools and applications (pp. 353-372). Amsterdam: Springer.

Paxinos, R., Wright, A., Day, V., et al. (2008). Marine spatial planning: Ecosystem-based zoning methodology for marine management in South Australia. Journal of Conservation Planning, 4, $37-59$.

Raworth, K. (2012). A safe and just space for humanity: Can we live within the doughnut? Oxfam discussion papers.

Robinson, L. A., Culhane, F. E., Baulcomb, C., et al. (2014). Towards delivering ecosystem-based marine management: The ODEMM approach. ODEMM.

Rodriguez, N. J. I. (2017). A comparative analysis of holistic marine management regimes and ecosystem approach in marine spatial planning in developed countries. Ocean \& Coastal Management, 137, 185-197. https://doi.org/10.1016/j.ocecoaman.2016.12.023.

Romero-Lankao, P., Gnatz, D. M., Wilhelmi, O., \& Hayden, M. (2016). Urban sustainability and resilience: From theory to practice. Sustain, 8, 1-19. https://doi.org/10.3390/su8121224.

Sandersen, H. T., Mikkelsen, E., Moksness, E., \& Vølstad, J. H. (2013). Knowledge issues in ICZM and EBM applied on small geographic scales: Lessons from a case study in Risør, Norway. In 
E. Moksness, E. Dahl, \& J. Støttrup (Eds.), Global challenges in integrated coastal zone management. Wiley.

Sardà, R., O’Higgins, T., Cormier, R., et al. (2014). A proposed ecosystem-based management system for marine waters: Linking the theory of environmental policy to the practice of environmental management. Ecology and Society, 19, 51. https://doi.org/10.5751/ES-07055190451.

Smith, D. C., Fulton, E. A., Apfel, P., et al. (2017). Implementing marine ecosystem-based management: Lessons from Australia. ICES Journal of Marine Science, 74 (7), 1990-2003. https://doi.org/10.1093/icesjms/fsx113.

Soma, K., van Tatenhove, J., \& van Leeuwen, J. (2015). Marine governance in a European context: Regionalization, integration and cooperation for ecosystem-based management. Ocean \& Coastal Management, 117, 4-13. https://doi.org/10.1016/j.ocecoaman.2015.03.010.

Stern, P. C., Young, O. R., \& Druckman, D. (1992). Global environmental change: Understanding the human dimensions. Washington, DC: The National Academies Press. https://doi.org/ $10.17226 / 1792$

UN Environment. (2018). Conceptual guidelines for the application of marine spatial planning and integrated coastal zone management approaches to support the achievement of sustainable development goal targets 14.1 and 14.2. UN Regional Seas Reports and Studies No. 207.

UNEP. (2010). Marine and coastal ecosystem-based management. An introductory guide to managing oceans and coasts better. UNEP.

UNEP. (2012). Synthesis document on the experience and use of marine spatial planning. UNEP/ CBD/SBSTTA/16/INF/18.

Yaffee, S. L. (1999). Three faces of ecosystem management. Conservation Biology, 13, 713-725.

Yasuhara, M., Hunt, G., Breitburg, D., et al. (2012). Human-induced marine ecological degradation: Micropaleontological perspectives. Ecology and Evolution, 2, 3242-3268. https://doi.org/ 10.1002/ece3.425.

Open Access This chapter is licensed under the terms of the Creative Commons Attribution 4.0 International License (http://creativecommons.org/licenses/by/4.0/), which permits use, sharing, adaptation, distribution and reproduction in any medium or format, as long as you give appropriate credit to the original author(s) and the source, provide a link to the Creative Commons licence and indicate if changes were made.

The images or other third party material in this chapter are included in the chapter's Creative Commons licence, unless indicated otherwise in a credit line to the material. If material is not included in the chapter's Creative Commons licence and your intended use is not permitted by statutory regulation or exceeds the permitted use, you will need to obtain permission directly from the copyright holder.

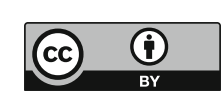

